\title{
Vertical distribution, behavior, chemical composition and metabolism of Stauroteuthis syrtensis (Octopoda: Cirrata) in the northwest Atlantic
}

\author{
Charles A. Jacoby ${ }^{1, *}$, Marsh J. Youngbluth ${ }^{2}$, Jessica R. Frost ${ }^{1,8}{ }^{,}$Per R. Flood ${ }^{3}$, \\ Franz Uiblein ${ }^{4}$, Ulf Båmstedt ${ }^{5}$, Francesc Pagès ${ }^{6, \mathrm{~F}}$, David Shale ${ }^{7}$ \\ ${ }^{1}$ University of Florida, Gainesville, Florida 32653, USA \\ ${ }^{2}$ Harbor Branch Oceanographic Institution at Florida Atlantic University, 5600 Highway 1 North, Fort Pierce, Florida 34946, USA \\ ${ }^{3}$ Bathybiologica A/S, Gerhard Grans vei 58, 5081 Bergen, Norway \\ ${ }^{4}$ Institute of Marine Research, Nordnesgaten 33, PB 1870 Nordnes, 5817 Bergen, Norway \\ ${ }^{5}$ Umeå Marine Sciences Centre, Norrbyn, 91020 Hörnefors, Sweden \\ ${ }^{6}$ Institut de Ciències del Mar (CSIC), Passeig Marítim de la Barceloneta 37-49, 08003 Barcelona, Spain \\ ${ }^{7} 14$ Victoria Avenue, Swanage, Dorset BH19 1AN, UK \\ ${ }^{8}$ Present address: Institute for Hydrobiology and Fisheries Science, University of Hamburg, Olbersweg 24, \\ 22767 Hamburg, Germany
}

\begin{abstract}
The cirrate octopod Stauroteuthis syrtensis is a mesopelagic species commonly collected in the North Atlantic. Individuals were observed at depths $>600 \mathrm{~m}$ and typically within $100 \mathrm{~m}$ of the bottom in three $\sim 900 \mathrm{~m}$ deep canyons indenting the southern edge of Georges Bank. When first sighted, most octopods were floating passively with their webbed arms gathered into a small ball. When disturbed, they expanded their webs to form a 'balloon' shape, swam slowly by sculling their fins, pulsed their webs like medusae and, in some cases, streamlined their arms and webs and moved away smoothly by rapidly sculling their fins. The bodies of 9 octopods comprised 92 to $95 \%$ water, with tissue containing 9 to $22 \%$ carbon (C) and 2 to $4 \%$ nitrogen (N). These values were similar to those reported for medusae and ctenophores. Oxygen $\left(\mathrm{O}_{2}\right)$ consumption rates of 4.6 to $25.8 \mu \mathrm{mol} \mathrm{O}_{2} \mathrm{~g}^{-1} \mathrm{C} \mathrm{h}^{-1}$ were within ranges reported for medusae, ctenophores, and deep-water cephalopods. The stomachs of $S$. syrtensis, dissected immediately after capture, contained only the calanoid copepod Calanus finmarchicus. Calculations indicated that $S$. syrtensis need 1.3 to 30.1 ind. $\mathrm{d}^{-1}$ of $C$. finmarchicus to meet their measured metabolic demand. Excretion rates $\left(0.3\right.$ to $12.4 \mu \mathrm{g} \mathrm{NH}_{4}{ }^{+} \mathrm{g}^{-1} \mathrm{C} \mathrm{h}^{-1}$ and 0.06 to $4.83 \mu \mathrm{g} \mathrm{PO}_{4}{ }^{3-}$ $\mathrm{g}^{-1} \mathrm{C} \mathrm{h}^{-1}$ ) were at least an order of magnitude lower than rates reported for other octopods or gelatinous zooplankters. O:N ratios (11 to 366) suggested that $S$. syrtensis catabolized lipids, which may be supplied by $C$. finmarchicus. Vertical distribution, relatively torpid behavior and low metabolic rates characterized S. syrtensis as a benthopelagic and relatively passive predator on copepods.
\end{abstract}

KEY WORDS: Stauroteuthis syrtensis · Respiration · Excretion ' Chemical composition · Vertical distribution $\cdot$ Behavior

Resale or republication not permitted without written consent of the publisher

\section{INTRODUCTION}

Stauroteuthis syrtensis Verrill, 1879 is a deep-water octopod that occurs throughout the North Atlantic (Collins \& Henriques 2000, Collins et al. 2002, Collins \& Villanueva 2006). Most specimens have been collected at depths of 500 to $4000 \mathrm{~m}$, with many speci- mens caught in bottom trawls and higher abundances reported at depths of 1500 to $2500 \mathrm{~m}$ (e.g. Collins \& Henriques 2000, Collins et al. 2001, 2002, Vecchione \& Galbraith 2001, Vecchione \& Pohle 2002). Specimens captured at depths of 250 to $500 \mathrm{~m}$ off Greenland and Iceland provided evidence that the vertical distribution of this species was influenced by water temperature as 
Iceland provided evidence that the vertical distribution of this species was influenced by water temperature as much as, or more so than, depth (Collins 2002).

Stauroteuthis syrtensis has been observed to display a variety of behaviors, including swimming by sculling its paired fins, swimming via medusoid contractions of its web complex, inflating its web to varying degrees, and inverting its arms and web to expose suckers that differ from those of most octopods in that they contain bioluminescent photophores and are not adhesive (Vecchione \& Young 1997, Johnsen et al. 1999, Collins et al. 2002, Collins \& Villanueva 2006). Inflation and inversion of the web have been hypothesized to be defensive responses to disturbance or behaviors involved in capturing small crustacean prey attracted by the bioluminescence emanating from the suckers (Vecchione \& Young 1997, Johnsen et al. 1999, Collins et al. 2002). A secondary web that links the arms to the primary web in $S$. syrtensis and other Cirroteuthidae facilitates behaviors such as medusoid swimming, inflation and inversion.

Similar to other members of the suborder Cirrata, Stauroteuthis syrtensis possesses a fragile, semi-gelatinous body (Collins \& Henriques 2000, Collins et al. 2002), which suggests that the metabolic rates of $S$. syrtensis should resemble those of medusae and ctenophores, rather than the higher respiratory demands of more muscular cephalopods. In addition, if S. syrtensis ambushes prey, perhaps by using its bioluminescent suckers as lures, then its $\mathrm{O}_{2}$ consumption rates should be relatively low and similar to other deep-water cephalopods that have replaced visually guided pursuit of prey with an ambush strategy (Childress \& Mickel 1985, Seibel et al. 2000, Seibel \& Carlini 2001).

The present study provides the first measurements of $\mathrm{O}_{2}$ consumption and $\mathrm{NH}_{4}{ }^{+}$and $\mathrm{PO}_{4}{ }^{3-}$ excretion for Stauroteuthis syrtensis collected in Oceanographer Canyon, a deep-water canyon that indents the southern boundary of Georges Bank. Furthermore, in situ observations from crewed submersibles documented the vertical distribution and behavior of these octopods in this and 2 adjacent canyons, Hydrographer and Lydonia Canyons.

\section{MATERIALS AND METHODS}

Observation and collection. Stauroteuthis syrtensis were observed from 'Johnson-Sea-Link' submersibles, which operate to a depth of $914 \mathrm{~m}$ (Youngbluth 1984). Visual observations were made in Hydrographer, Oceanographer and Lydonia Canyons during June 1995, September 2001, June 2002, September 2003, September 2004, and October 2005 (Fig. 1). Individuals for studies of respiration and excretion were collected

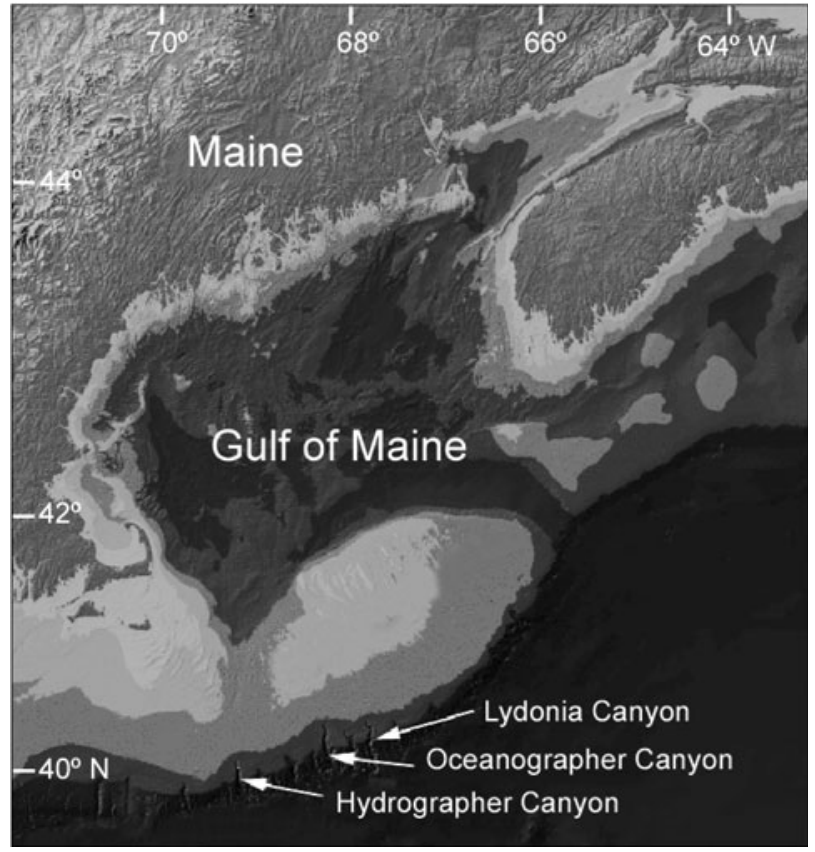

Fig. 1. Locations of sampling for cirrate octopods Stauroteuthis syrtensis

in Oceanographer Canyon during September 2004. At the sampling stations, dates, times, depths, temperatures, salinities, and concentrations of dissolved $\mathrm{O}_{2}$ were recorded with Seabird SBE 25 Sealoggers.

Octopods and water samples without visible organisms (i.e. controls) were collected in 6.51 acrylic samplers that had been washed with a $1 \mathrm{~mol} \mathrm{l}^{-1} \mathrm{HCl}$ solution prior to use (Tietze \& Clark 1986). An individual sampler contained either 1 individual of Stauroteuthis syrtensis or a control water sample.

Measurements of respiration and excretion. Upon return to the surface, samplers were transferred quickly from the submersible to a dark room maintained at an air temperature of 4 to $5^{\circ} \mathrm{C}$, which mimicked in situ conditions. Within $28 \mathrm{~h}$ of capture, all octopods except the largest individual (wet weight, $\mathrm{WW}=158 \mathrm{~g}$ ) were transferred gently into 0.5 to $2.2 \mathrm{l}$ acrylic chambers. These smaller chambers, which acted as respirometers, were filled and sealed in a manner that avoided the formation or trapping of air bubbles. When additional water was needed to fill a smaller chamber, seawater collected in Niskin bottles from 800 to $900 \mathrm{~m}$ water depth was added. The largest individual was too large for the smaller chambers, so it was incubated in the original 6.51 sampler, which served as a respirometer.

An experiment consisted of one or more respirometers, each holding a single octopod, and a respirometer that contained water without visible organisms, which yielded measures of background changes in concen- 
trations of dissolved $\mathrm{O}_{2}, \mathrm{NH}_{4}{ }^{+}$and $\mathrm{PO}_{4}{ }^{3-}$. Antibiotics were not added to any of the respirometers. During experiments, all respirometers were kept in darkness at 4 to $5^{\circ} \mathrm{C}$ and ambient pressure $(1 \mathrm{~atm})$ for 9 to $22 \mathrm{~h}$.

$\mathrm{O}_{2}$ consumption was measured concurrently in control and experimental respirometers with a noninvasive, micro-optode system (PreSens; http://microoptode. com/html/start.html). $\mathrm{O}_{2}$ concentrations ( $\mu \mathrm{mol} \mathrm{O}_{2} \mathrm{l}^{-1}$ ) were logged at $1 \mathrm{~s}$ intervals. In some experiments, recordings were conducted for 30 min periods, separated by 30 to 60 min intervals, so that $\mathrm{O}_{2}$ consumption could be tracked in multiple respirometers using a single micro-optode system. Records from the initial 2 to $6 \mathrm{~h}$ were excluded from estimates of $\mathrm{O}_{2}$ consumption to eliminate periods of equilibration and acclimation. Rates of $\mathrm{O}_{2}$ consumption were calculated using leastsquares linear regression, and only the results of statistically significant regressions were used. If controls yielded statistically significant rates of $\mathrm{O}_{2}$ consumption, these values were subtracted from the appropriate experimental rates to account for respiration by organisms other than Stauroteuthis syrtensis.

Winkler titrations were performed on duplicate water samples removed from representative respirometers (Wetzel \& Likens 2000). When compared to records from micro-optodes, these measurements provided a check on the reliability of the time series.

Duplicate samples for estimating $\mathrm{NH}_{4}{ }^{+}$excretion and either duplicate or single samples for estimating $\mathrm{PO}_{4}{ }^{3-}$ excretion were extracted from an acrylic sampler at the beginning of an experiment, i.e. an initial control, and from control and experimental respirometers at the end of the incubation periods. Due to a contaminated filtering apparatus and unavoidable delays in obtaining a replacement bulb for the spectrophotometer, these samples were not filtered, and they were frozen at $-20^{\circ} \mathrm{C}$ for up to $11 \mathrm{~d}$ before analysis. Concentrations were determined by standard spectrophotometric methods using a Spectronic Genesys 8 spectrophotometer, with a $10 \mathrm{~cm}$ cuvette at $640 \mathrm{~nm}$ for $\mathrm{NH}_{4}{ }^{+}$and $882 \mathrm{~nm}$ for $\mathrm{PO}_{4}{ }^{3-}$ (Strickland \& Parsons 1972, American Public Health Association 1989). Rates of $\mathrm{NH}_{4}^{+}$and $\mathrm{PO}_{4}{ }^{3-}$ excretion not attributable to Stauroteuthis syrtensis were calculated using concentrations in the appropriate initial and final controls, and these values were subtracted from rates calculated using final concentrations in experimental respirometers and initial concentrations from the appropriate controls. Only positive differences were reported.

Following experiments, Stauroteuthis syrtensis were transferred to tared pans and frozen $\left(-20^{\circ} \mathrm{C}\right)$. In a shore-based laboratory, each frozen specimen was thawed and its WW was recorded to the nearest $0.1 \mathrm{~g}$. After determination of WW, specimens were dried at $60^{\circ} \mathrm{C}$ until a consistent dry weight (DW) was obtained to the nearest $0.1 \mathrm{~g}$ over a period of 2 to $4 \mathrm{~d}$. Each dried specimen was thoroughly homogenized, and aliquots were sent to the Analytical Laboratory of the Marine Science Institute at the University of California, Santa Barbara, where proportions of $\mathrm{C}, \mathrm{H}$ and $\mathrm{N}$ were determined using a Perkin-Elmer Model 240 elemental analyzer and an acetanilide standard.

\section{RESULTS}

\section{Vertical distribution}

Eighty-one Stauroteuthis syrtensis were sighted in 4 canyons during 24 dives conducted during 6 cruises. Approximately $90 \%$ of the octopods were recorded as single individuals in a field of view that encompassed approximately $400 \mathrm{~m}^{3}$ of water. The maximum number of individuals sighted in a single field of view was 5; this observation took place at approximately 14:00 h on 7 September 2002 at a depth of $848 \mathrm{~m}$ in a water column of $1000 \mathrm{~m}$ in Oceanographer Canyon.

Stauroteuthis syrtensis were sighted at depths of 603 to $908 \mathrm{~m}$ (mean $\pm \mathrm{SE}: 780.9 \pm 8.3 \mathrm{~m}$; Table 1$)$. The octopods were observed from $\sim 0.5$ to $258 \mathrm{~m}$ above the bottom $(100.1 \pm 7.2 \mathrm{~m})$. The 35 individuals observed during daytime dives (14:00 to $17: 00 \mathrm{~h}$ ) and the 46 individuals observed during nighttime dives (20:00 to 00:30 h) were sighted at similar, but significantly different distances above the bottom (daytime 81.2 $\pm 10.6 \mathrm{~m}$, nighttime $114.4 \pm 9.2 \mathrm{~m}, t=-2.37, \mathrm{df}=73, \mathrm{p}<0.05)$. Octopods were collected or sighted in water with temperatures ranging from 4.20 to $6.14^{\circ} \mathrm{C}\left(4.67 \pm 0.06^{\circ} \mathrm{C}\right)$, salinities ranging from 34.86 to 35.03 psu (34.96 \pm $0.01 \mathrm{psu}$ ), and dissolved $\mathrm{O}_{2}$ concentrations ranging from 3.00 to $5.54 \mathrm{ml} \mathrm{l}^{-1}\left(4.83 \pm 0.16 \mathrm{ml} \mathrm{l}^{-1}\right)$ (Table 1).

\section{Behavior}

When first sighted, most Stauroteuthis syrtensis were floating passively, with their arms contracted, webs curled into a small ball and eyes hooded. When disturbed, seemingly by light, noise, or turbulence from the submersible, octopods would expose their eyes and unfold their webs, which they often inflated. Initially, octopods tended to move away from the submersible by sculling their fins or pulsing their webs like a medusa. Eventually, some octopods streamlined their webbed arms behind their bodies and increased the rate at which their fins sculled to move away from the submersible smoothly and more rapidly.

Neither hunting nor feeding behavior was observed, which was expected given the response of the octopods to disturbance from the submersibles. The guts of 
Table 1. Stauroteuthis syrtensis. Details for collections and sightings of cirrate octopods from Oceanographer Canyon for use in metabolic experiments. Salinity was consistantly 35 psu. -: data not applicable

\begin{tabular}{|c|c|c|c|c|c|c|c|}
\hline Octopod & Date & Latitude, Longitude & $\begin{array}{l}\text { Time of } \\
\text { collection } \\
\text { (h) }\end{array}$ & $\begin{array}{l}\text { Depth of } \\
\text { collection } \\
\text { or sighting } \\
\text { (m) }\end{array}$ & $\begin{array}{l}\text { Depth of } \\
\text { bottom } \\
\text { (m) }\end{array}$ & $\begin{array}{c}\text { Temperature } \\
\left({ }^{\circ} \mathrm{C}\right)\end{array}$ & $\begin{array}{c}\text { Dissolved } \\
\mathrm{O}_{2} \\
\left(\mathrm{ml} \mathrm{l}^{-1}\right)\end{array}$ \\
\hline 1 & 17 Sep 2004 & $40^{\circ} 20.182 \mathrm{~N}, 68^{\circ} 08.277 \mathrm{~W}$ & $14: 45$ & 888 & 930 & 4.30 & 5.52 \\
\hline 2 & & & & 807 & & 4.37 & 5.48 \\
\hline 3 & & $40^{\circ} 20.427 \mathrm{~N}, 68^{\circ} 08.291 \mathrm{~W}$ & $22: 42$ & 784 & 910 & 4.60 & 5.35 \\
\hline 4 & & & $22: 53$ & 725 & & 4.80 & 5.25 \\
\hline 5 & & & $21: 48$ & 821 & & 4.59 & 5.36 \\
\hline 6 & & & $21: 25$ & 908 & & 4.44 & 5.42 \\
\hline 7 & 22 Sep 2004 & $40^{\circ} 19.996 \mathrm{~N}, 68^{\circ} 07.997 \mathrm{~W}$ & $14: 45$ & 741 & 913 & 4.74 & 5.28 \\
\hline 8 & & $40^{\circ} 20.363 \mathrm{~N}, 68^{\circ} 08.250 \mathrm{~W}$ & $21: 35$ & 857 & 910 & 4.86 & 5.21 \\
\hline 9 & 23 Sep 2004 & $40^{\circ} 20.057 \mathrm{~N}, 68^{\circ} 07.890 \mathrm{~W}$ & $21: 38$ & 861 & 912 & 4.67 & 5.30 \\
\hline- & $\begin{array}{l}\text { All collections \& sightings } \\
(\text { mean } \pm \mathrm{SE})\end{array}$ & - & - & $\begin{array}{l}780.9 \\
\pm 8.3\end{array}$ & $\begin{array}{l}881.0 \\
\pm 6.4\end{array}$ & $\begin{aligned} & 4.66 \\
\pm & 0.063\end{aligned}$ & $\begin{array}{c}4.829 \\
\pm 0.155\end{array}$ \\
\hline
\end{tabular}

3 individuals captured during 3 different dives were dissected immediately after completion of the dives. The stomachs contained 8 to 25 intact or partially digested Calanus finmarchicus. The calanoids exhibited no evidence of dismemberment, and they were mostly Stage V copepodites along with a few adults. These crustaceans were never observed in water samples used as controls in metabolic experiments, so it was unlikely that the octopods fed after capture. C. finmarchicus occurred in all of the canyons and, in 2002, a series of 26 samples taken at depths of 430 to $750 \mathrm{~m}$ with a suction sampler mounted on the submersible yielded a mean abundance $( \pm \mathrm{SE})$ of $31.2 \pm 3.4$ ind. $\mathrm{m}^{-3}$ across the 3 canyons.

\section{Chemical composition, $\mathrm{O}_{2}$ consumption, and excretion}

Nine Stauroteuthis syrtensis were used in experiments (Table 1). All octopods were captured within $185 \mathrm{~m}$ of the sea floor in a water column of 910 to $930 \mathrm{~m}$. WW and DW of these octopods varied by an order of magnitude (Table 2). Water comprised 92 to $96 \%$ of the entire bodies of all octopods (Table 2). C:N ratios ranged from 4.57 to 7.60 , with a mean $( \pm \mathrm{SE})$ of $5.77 \pm 0.31$. WW, DW and C contents were normally distributed and homoscedastic after $\log _{10}$ transformation (Ryan-Joiner tests for
$\mathrm{WW}=0.98, \mathrm{df}=8, \mathrm{p}>0.10 ; \mathrm{DW}=0.98, \mathrm{df}=8, \mathrm{p}>0.10 ;$ and $\mathrm{C}$ content $=0.98, \mathrm{df}=8, \mathrm{p}>0.10 ;$ Cochran's tests for DW versus WW $=0.54, \mathrm{df}=2,8, \mathrm{p}>0.05 ; \mathrm{C}$ content versus WW $=0.24, \mathrm{df}=2,8, \mathrm{p}>0.05$; and $\mathrm{C}$ content versus $\mathrm{DW}=0.60, \mathrm{df}=2,8, \mathrm{p}>0.05)$. Statistically significant linear regressions that explained $>80 \%$ of the variation in the data revealed that all 3 measures of size were related and reliable (Fig. 2).

Duplicate Winkler titrations from 8 of the 9 experiments had coefficients of variation $<5 \%$. These data were homoscedastic and normally distributed (Cochran's test $=0.55, \mathrm{df}=2,7, \mathrm{p}>0.05 ;$ Ryan-Joiner tests for Winkler values $=0.94, \mathrm{df}=7, \mathrm{p}>0.10$; and microoptode values $=0.92, \mathrm{df}=7, \mathrm{p}>0.05)$. A statistically significant linear regression indicated that measure-

Table 2. Stauroteuthis syrtensis. Weights and elemental composition of cirrate octopods. DW: dry weight

\begin{tabular}{|lcccccccc|}
\hline \multirow{2}{*}{ Octopod } & \multicolumn{3}{c}{ Weight (g) } & Proportion & \multicolumn{3}{c}{ Proportion of DW } & \multirow{2}{*}{ C content } \\
& Wet & Dry & of water & C & H & N & $(g)$ \\
\hline 1 & 74.2 & 3.5 & 0.95 & 0.198 & 0.033 & 0.032 & 0.69 \\
2 & 13.2 & 1.1 & 0.92 & 0.144 & 0.026 & 0.024 & 0.16 \\
3 & 147.7 & 6.8 & 0.95 & 0.174 & 0.029 & 0.031 & 1.18 \\
4 & 21.9 & 1.0 & 0.95 & 0.091 & 0.020 & 0.018 & 0.09 \\
5 & 38.8 & 1.7 & 0.96 & 0.108 & 0.021 & 0.024 & 0.18 \\
6 & 13.2 & 0.7 & 0.95 & 0.156 & 0.026 & 0.021 & 0.11 \\
7 & 21.9 & 1.8 & 0.92 & 0.181 & 0.030 & 0.028 & 0.33 \\
8 & 50.2 & 2.7 & 0.95 & 0.107 & 0.020 & 0.022 & 0.29 \\
9 & 158.1 & 9.6 & 0.94 & 0.224 & 0.039 & 0.042 & 2.16 \\
Mean & 59.91 & 3.21 & 0.943 & 0.1537 & 0.0271 & 0.0269 & 0.577 \\
\pm SE & \pm 18.76 & \pm 1.01 & \pm 0.005 & \pm 0.0151 & \pm 0.0021 & \pm 0.0024 & \pm 0.230 \\
\hline
\end{tabular}



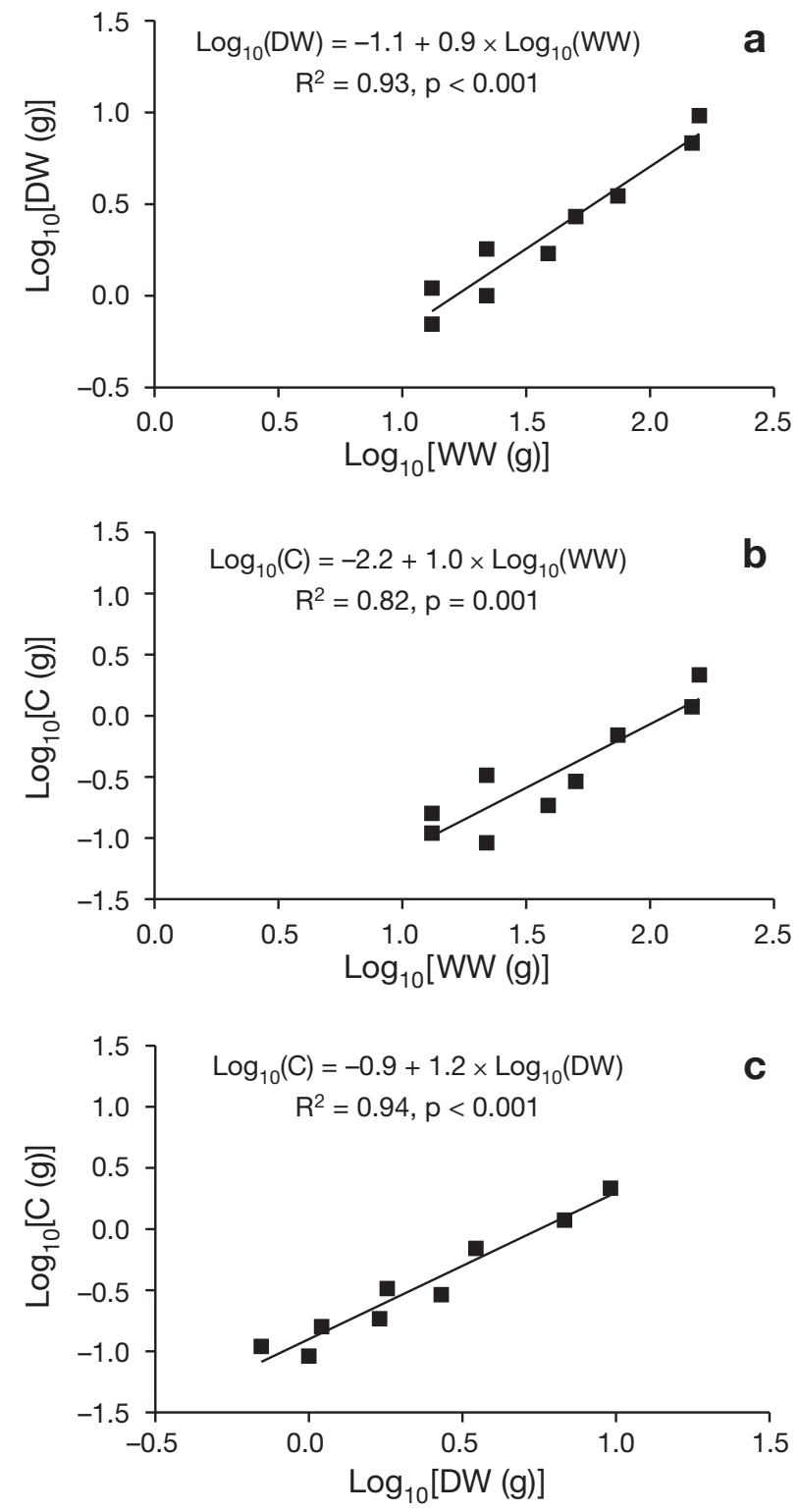

Fig. 2. Stauroteuthis syrtensis. Linear regression of $\log _{10}$-transformed dry weight (DW, in g) (a) on wet weight (WW, in g), (b) C content (in g) on WW, and (c) C content on DW for cirrate octopods

ments taken by micro-optodes were reliable measures of relative $\mathrm{O}_{2}$ consumption, with micro-optodes consistently yielding higher concentrations than the Winkler titrations (micro-optode value $=1.35 \times$ Winkler value, $\left.F=3541.35, \mathrm{df}=1,7, \mathrm{p}<0.001, \mathrm{R}^{2}=0.91\right)$.

All octopods became quiescent and ventilated calmly after an initial period of acclimation. All experiments yielded statistically significant regressions, with $\mathrm{O}_{2}$ consumption in respirometers containing octopods being 1 to 2 orders of magnitude greater than $\mathrm{O}_{2}$ consumption in controls. Stauroteuthis syrtensis consumed 5 to $35 \%$ of the $\mathrm{O}_{2}$ available at the start of the experi- ments. Weight-specific and C-specific rates of $\mathrm{O}_{2}$ consumption varied among octopods, with ranges of 0.031 to $0.243 \mu \mathrm{mol} \mathrm{O} \mathrm{g}^{-1} \mathrm{WW} \mathrm{h}^{-1}, 0.576$ to $3.192 \mu \mathrm{mol} \mathrm{O}$ $\mathrm{g}^{-1} \mathrm{DW} \mathrm{h}^{-1}$, and 4.631 to $25.788 \mu \mathrm{mol} \mathrm{O} \mathrm{g}^{-1} \mathrm{C} \mathrm{h}^{-1}$ (Table 3). With the values for Octopod 9 excluded, weight-specific and $\mathrm{C}$-specific rates of $\mathrm{O}_{2}$ consumption decreased as body size increased, with the models fit to WW and C content explaining a larger amount of variation in the data (Fig. 3). Octopod 9 was the largest individual and, although there was no evidence of unusual behavior, this individual may have had an imperceptible injury resulting in stress and greater $\mathrm{O}_{2}$ consumption. As expected, data standardized to DW varied more than data standardized to $\mathrm{C}$ content due to the difficulty of removing bound water from gelatinous tissue (Youngbluth et al. 1988).

Concentrations of $\mathrm{NH}_{4}{ }^{+}$and $\mathrm{PO}_{4}{ }^{3-}$ in 4 or 5 respirometers containing Stauroteuthis syrtensis were distinguishable from changes in controls (Table 4). However, most concentrations were near detection limits regardless of holding times. A small individual, Octopod 6 (Table 2), excreted 3 to 45 times as much $\mathrm{NH}_{4}{ }^{+}$as the other octopods (Table 4). With this individual included, the weight-specific and C-specific excretion rates for $\mathrm{NH}_{4}{ }^{+}$decreased for larger S. syrtensis, with the curves explaining 92 to $96 \%$ of the variation in the data (Fig. 4). Similar decreasing relationships explained 47 to $70 \%$ of the variation in the $\mathrm{PO}_{4}{ }^{3-}$ data when the values recorded for Octopod 3 were excluded (Fig. 5). This octopod was one of the largest (Table 2), and it excreted more $\mathrm{PO}_{4}{ }^{3-}$ than predicted by the model, perhaps due to an imperceptible injury. Atomic ratios for $\mathrm{O}: \mathrm{N}, \mathrm{O}: \mathrm{P}$ and $\mathrm{N}: \mathrm{P}$, calculated from values measured during single experimental runs, ranged from 11.01-365.83, 376.52-11471.99 and 1.03-135.84, respectively (Table 5). Removing Octopod 3, which had a relatively low rate of $\mathrm{NH}_{4}{ }^{+}$excre-

Table 3. Stauroteuthis syrtensis. Weight-specific and C-specific $\mathrm{O}_{2}$ consumption rates for cirrate octopods. WW: wet weight; DW: dry weight

\begin{tabular}{|c|c|c|c|}
\hline \multirow{2}{*}{ Octopod } & \multirow{2}{*}{$\mathrm{g}^{-1} \mathrm{WW} \mathrm{h}^{-1}$} & \multirow{2}{*}{ nol $\mathrm{O}_{2}$ consume } & \multirow[b]{2}{*}{$\mathrm{g}^{-1} \mathrm{Ch}^{-1}$} \\
\hline & & & \\
\hline 1 & 0.043 & 0.918 & 4.631 \\
\hline 2 & 0.228 & 2.726 & 18.881 \\
\hline 3 & 0.072 & 1.565 & 9.013 \\
\hline 4 & 0.107 & 2.354 & 25.788 \\
\hline 5 & 0.092 & 2.108 & 19.448 \\
\hline 6 & 0.098 & 1.851 & 11.830 \\
\hline 7 & 0.243 & 2.963 & 16.363 \\
\hline 8 & 0.031 & 0.576 & 5.363 \\
\hline 9 & 0.194 & 3.192 & 14.220 \\
\hline Mean & 0.123 & 2.028 & 13.949 \\
\hline$\pm \mathrm{SE}$ & \pm 0.026 & \pm 0.299 & \pm 2.327 \\
\hline
\end{tabular}



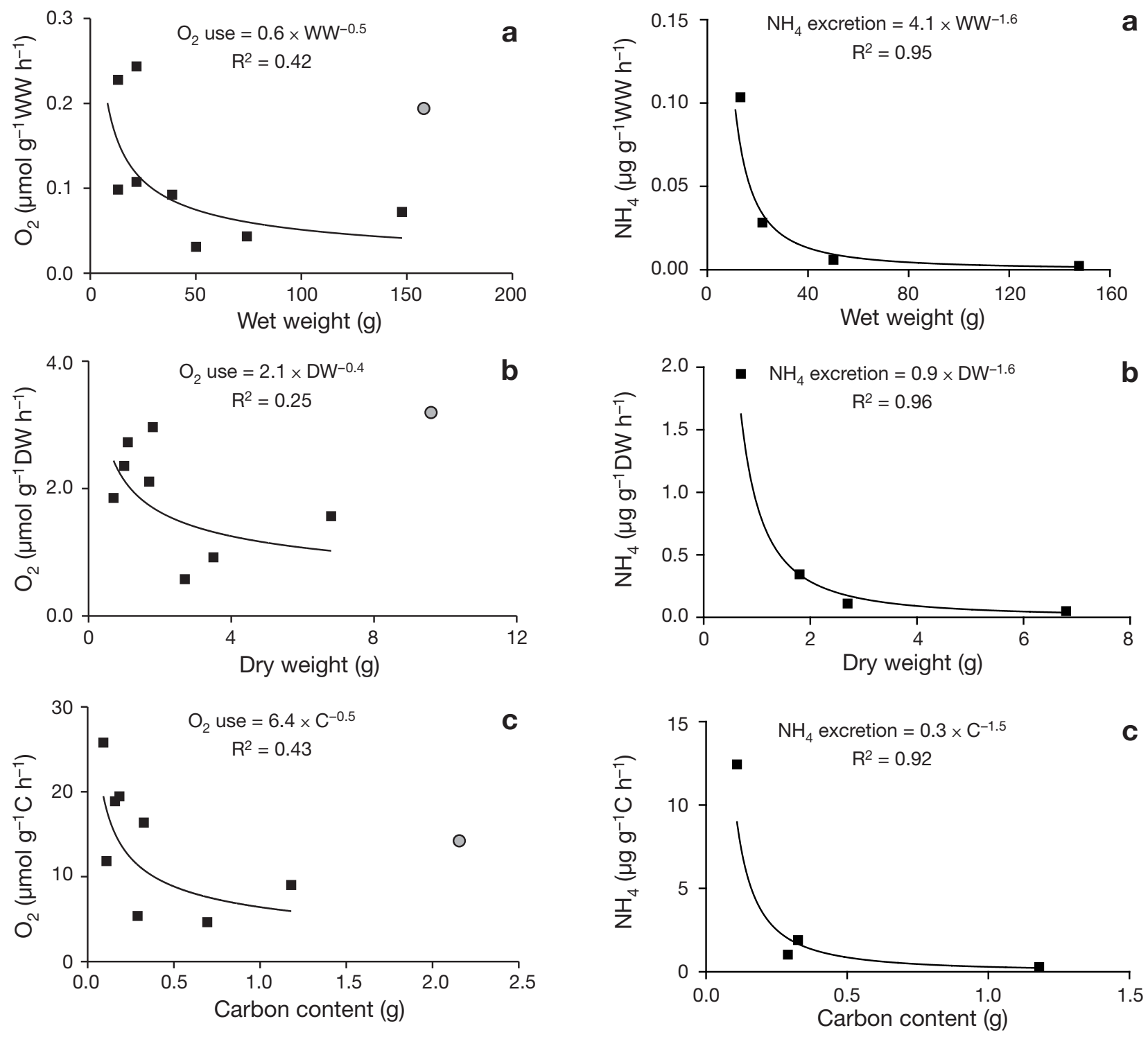

Fig. 3. Stauroteuthis syrtensis. Rates of $\mathrm{O}_{2}$ consumption versus (a) WW, (b) DW, and (c) C content for cirrate octopods. Values for Octopod 9 (grey circle) excluded from data used to fit the curve. Definitions as in Fig. 1

Fig. 4. Stauroteuthis syrtensis. Rates of $\mathrm{NH}_{4}{ }^{+}$excretion versus (a) WW, (b) DW, and (c) C content for cirrate octopods. Definitions as in Fig. 1

Table 4. Stauroteuthis syrtensis. Weight-specific and C-specific $\mathrm{NH}_{4}{ }^{+}$and $\mathrm{PO}_{4}{ }^{3-}$ excretion rates. -: data unavailable

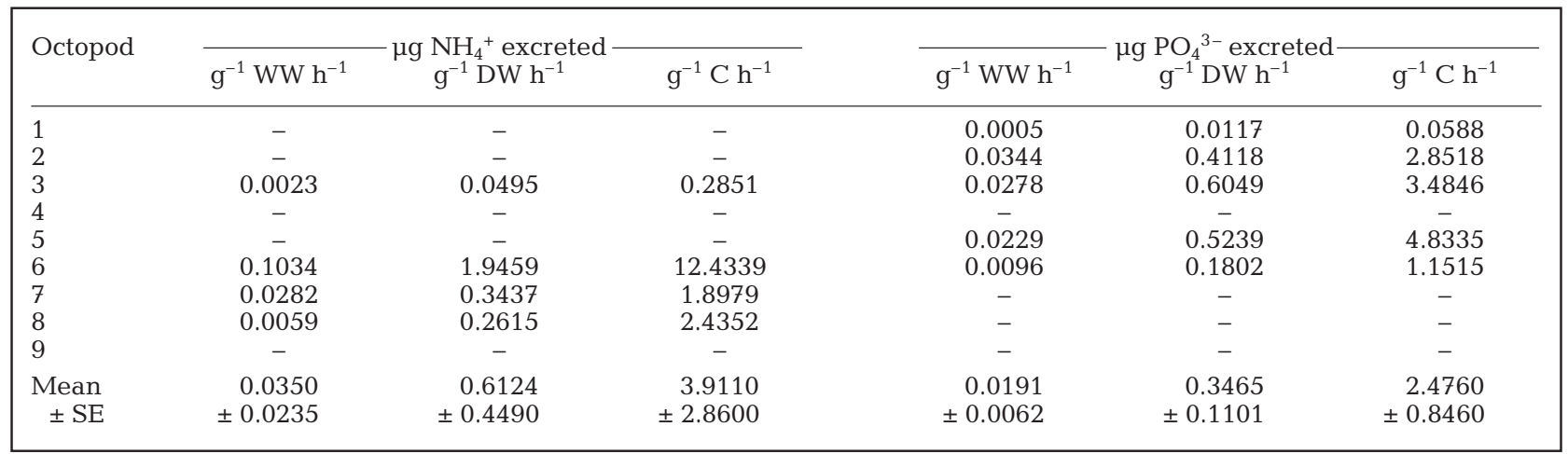



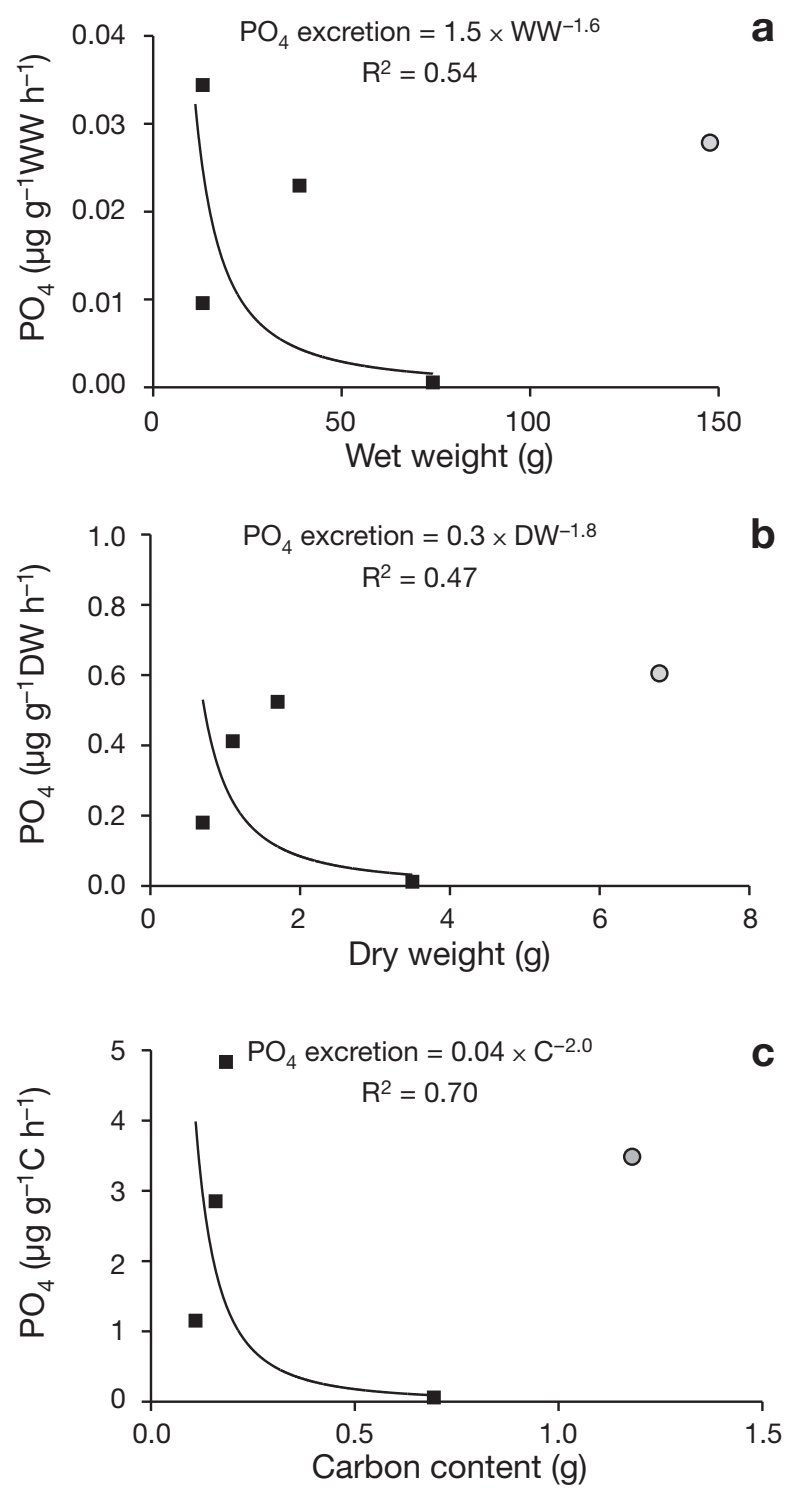

Fig. 5. Stauroteuthis syrtensis. Rates of $\mathrm{PO}_{4}{ }^{3-}$ excretion versus (a) WW, (b) DW, and (c) C content for cirrate octopods. Values for Octopod 3 (grey circle) excluded from data used to fit the curve. Definitions as in Fig. 1

tion, and Octopod 1, which had a relatively low rate of $\mathrm{PO}_{4}{ }^{3-}$ excretion, yielded a single value of 135.84 for $\mathrm{N}: \mathrm{P}$ and mean ratios $( \pm \mathrm{SE}$ ) of $55.07 \pm 25.68$ for O:N and $855.38 \pm 245.56$ for O:P (Table 5).

\section{DISCUSSION}

Water (73 to $87 \%$ ) and protein (8 to $20 \%$ ) represent the primary components of cephalopod bodies, which yield estimates of 4 to $10 \% \mathrm{C}$ and 2 to $4 \% \mathrm{~N}$ relative to WW (Croxall \& Prince 1982, Krzynowek \& Murphy 1987, Moltschaniwskyj \& Semmens 2000). In compari-
Table 5. Stauroteuthis syrtensis. Ratios of oxygen (O) consumed to nitrogen $(\mathrm{N})$ and phosphorus $(\mathrm{P})$ excreted. -: data unavailable

\begin{tabular}{|lccc|}
\hline Octopod & O:N & O:P & N:P \\
\hline 1 & - & 11471.99 & - \\
2 & - & 963.75 & - \\
3 & 365.83 & 376.52 & 1.03 \\
4 & - & - & - \\
5 & - & 585.70 & - \\
6 & 11.01 & 1495.55 & 135.84 \\
7 & 99.76 & - & - \\
8 & 60.43 & - & - \\
9 & - & - & - \\
Mean \pm SE & $134.26 \pm$ & $2978.70 \pm$ & $68.43 \pm$ \\
& 79.30 & 2131.82 & 67.41 \\
Without Octopod 3 & \multicolumn{4}{|}{} \\
Mean \pm SE & $55.07 \pm$ & - & 135.84 \\
Without Octopod 1 & 25.68 & \multicolumn{4}{c}{} \\
Mean \pm SE & - & $855.38 \pm 245.56$ & - \\
\hline
\end{tabular}

son, Stauroteuthis syrtensis were composed of $>90 \%$ water, 3 to $7 \% \mathrm{C}$, and 0.6 to $1.4 \% \mathrm{~N}$. In addition, the chemical composition of $S$. syrtensis was more similar to values reported for various gelatinous zooplankton than to values reported for crustaceans or fishes (Bailey et al. 1995). S. syrtensis, various medusae and ctenophores have water contents $>90 \%$, C contents $<25 \%$ of DW, and N contents $<5 \%$ of DW. In contrast, crustaceans and fishes typically have water contents $<90 \%$, C contents $>35 \%$, and $\mathrm{N}$ contents $>5 \%$. Thus, the metabolic rates of $S$. syrtensis would be expected to be similar to those of gelatinous zooplankton.

$\mathrm{C}$-specific rates of $\mathrm{O}_{2}$ consumption recorded for Stauroteuthis syrtensis were higher than values reported for gelatinous zooplankton after scaling to a temperature of $4.5^{\circ} \mathrm{C}$ using a $Q_{10}$ of 2 (148 to $825 \mu l \mathrm{O}_{2}$ $\mathrm{g}^{-1} \mathrm{C} \mathrm{h}^{-1}$ in the present study versus 1 to $181 \mathrm{\mu l} \mathrm{O}_{2} \mathrm{~g}^{-1}$ $\mathrm{C} \mathrm{h}^{-1}$ in Bailey et al. 1995). In contrast, scaled, weightspecific respiration rates for $S$. syrtensis were at the lower end of ranges reported for cephalopods from shallow and deep water $\left(0.9\right.$ to $7.8 \mu \mathrm{l} \mathrm{O}_{2} \mathrm{~g}^{-1} \mathrm{WW} \mathrm{h}^{-1}$ in the present study versus 0.3 to $190.2 \mathrm{\mu l} \mathrm{O}_{2} \mathrm{~g}^{-1} \mathrm{WW} \mathrm{h}^{-1}$ in Seibel et al. 1997, Daly \& Peck 2000, Seibel \& Childress 2000). Rates of $\mathrm{O}_{2}$ consumption for S. syrtensis were most similar to those reported for the vampire squid Vampyroteuthis infernalis and 2 deep-water octopods, Japetella heathi and J. diaphana (1.9 to $2.4 \mu \mathrm{l} \mathrm{O}_{2} \mathrm{~g}^{-1} \mathrm{WW} \mathrm{h}^{-1}, 3.5 \mu \mathrm{O} \mathrm{O}_{2} \mathrm{~g}^{-1} \mathrm{WW} \mathrm{h}^{-1}$, and 5.4 to $19.4 \mu \mathrm{l} \mathrm{O}_{2} \mathrm{~g}^{-1} \mathrm{WW} \mathrm{h}^{-1}$; Seibel et al. 1997). The similarity between the metabolic demands of $S$. syrtensis and $V$. infernalis may be related to the replacement of visual identification and pursuit of prey with a more passive strategy. It has been hypothesized that both 
species use bioluminescence to lure prey (Childress \& Mickel 1985, Johnsen et al. 1999, Collins \& Henriques 2000, Seibel et al. 2000, Seibel \& Carlini 2001, Robison et al. 2003). In addition to differential activity, some of the observed differences in $\mathrm{O}_{2}$ consumption may be related to allometric scaling, with larger animals consuming proportionally less $\mathrm{O}_{2}$, as observed in the present and previous studies (e.g. Seibel et al. 1997). Another consideration is that rates of $\mathrm{O}_{2}$ consumption measured at in situ pressures would be expected to be higher than the rates measured at sea level in the present and other studies (Bailey et al. 1994, 1995). Previous comparisons and those in the present study are related to measurements made at surface pressures.

$\mathrm{NH}_{4}{ }^{+}$and $\mathrm{PO}_{4}{ }^{3-}$ excretion rates for Stauroteuthis syrtensis were low. The rates were at least an order of magnitude lower than those reported for 2 species of ctenophores, a trachymedusan and a benthopelagic holothurian, i.e. 0.22 to $9.67 \mu \mathrm{g} \mathrm{NH}_{4}-\mathrm{N} \mathrm{g}^{-1} \mathrm{C} \mathrm{h}^{-1}$ and 0.02 to $1.58 \mu \mathrm{gO}_{4}-\mathrm{P} \mathrm{g}^{-1} \mathrm{C} \mathrm{h}^{-1}$ recorded in the present study versus 55.4 to $1389.5 \mu \mathrm{g} \mathrm{NH}_{4}-\mathrm{N} \mathrm{g}^{-1} \mathrm{C} \mathrm{h}^{-1}$ and 11.6 to $443.5 \mu \mathrm{gO}_{4}-\mathrm{P} \mathrm{g}^{-1} \mathrm{C} \mathrm{h}^{-1}$ reported in Bailey et al. (1994). In addition, rates of $\mathrm{NH}_{4}{ }^{+}$excretion for $S$. syrtensis were approximately 3 orders of magnitude less than rates reported for the Antarctic octopod Pareledone charcoti and the shallow-water octopod Octopus ocellatus: 0.04 to $1.51 \mu \mathrm{g} \mathrm{NH}_{4}-\mathrm{N} \mathrm{g}^{-1} \mathrm{DW} \mathrm{h}^{-1}$ and 0.002 to $0.080 \mu \mathrm{g} \mathrm{NH}_{4}-\mathrm{N}_{\mu \mathrm{g}^{-1}} \mathrm{WW} \mathrm{h}^{-1}$ in the present study versus $2521.2 \mu \mathrm{g} \mathrm{NH}_{4}-\mathrm{N} \mathrm{g}^{-1} \mathrm{DW} \mathrm{h}^{-1}$ in Daly \& Peck (2000) and 3 to $40 \mu \mathrm{g} \mathrm{NH}_{4}-\mathrm{N} \mathrm{\mu g}^{-1} \mathrm{WW} \mathrm{h}^{-1}$ in Segawa \& Nomoto (2002). The unavoidable need to store the samples before analysis may have resulted in lower concentrations, but excretion rates should have remained valid unless the loss of $\mathrm{NH}_{4}{ }^{+}$or $\mathrm{PO}_{4}{ }^{3-}$ was unequal across samples. The relatively low rates of $\mathrm{N}$ excretion also could be related to storage of $\mathrm{NH}_{4}{ }^{+}$or other nitrogenous cations as an evolutionary adaptation to increase buoyancy (Seibel et al. 2004).

The relatively low excretion rates translated into relatively high atomic ratios compared to values reported for other zooplankton. The O:N and O:P ratios for Stauroteuthis syrtensis (11 to 366 and 376 to 11 472, respectively) typically were higher than those reported for a variety of Antarctic zooplankton (7 to 20 and 43 to 304, respectively; Ikeda \& Mitchell 1982) and 2 species of ctenophores, a trachymedusan and a benthopelagic holothurian (9 to 24 and 50 to 317, respectively; Bailey et al. 1994). In addition, the O:N ratios for $S$. syrtensis were higher than those reported for Octopus vulgaris (3 to 15 ; Katsanevakis et al. 2005). Given the observed O:N ratios, S. syrtensis seemed to metabolize lipids (Mayzaud \& Conover 1988). In addition, the high O:P and $\mathrm{N}: \mathrm{P}$ ratios indicated that most octopods were not leaking phosphorus due to injury (Mayzaud \& Conover 1988).
Converting $\mathrm{O}_{2}$ consumption to $\mathrm{C}$ consumption by applying a respiratory quotient of 0.8 yielded estimates of metabolic demand expressed as \% body $\mathrm{C} \mathrm{d}^{-1}$ that ranged from 0.11 to $0.59 \% \mathrm{~d}^{-1}$, with a mean $( \pm \mathrm{SE})$ of $0.32 \pm 0.05 \%$ (Table 6 ). Examinations of gut contents from Stauroteuthis syrtensis expanded on previous reports that the octopods fed on unidentified copepods (e.g. Johnsen et al. 1999) and on the hypothesis that mucus secreted by buccal secretory glands entrapped prey that were then handled by the cirri (Vecchione \& Young 1997). In this case, only Calanus finmarchicus was found in the stomachs of S. syrtensis, with the condition of the prey indicating that they were swallowed whole. In addition, C. finmarchicus captured in the canyons during September 2004 had accumulated lipid stores (Miller et al. 1998), which S. syrtensis could have assimilated and stored, as reported for a species of Opisthoteuthis (Rosa et al. 2005), and eventually metabolized to produce the observed O:N ratios. Converting the C requirements of $S$. syrtensis to daily maintenance rations by assuming a contribution of $0.234 \mathrm{mg} \mathrm{C}$ ind.$^{-1}$ of $C$. finmarchicus yielded rations of 1.3 to 30.1 ind. $\mathrm{d}^{-1}$, with a mean $( \pm \mathrm{SE})$ of $6.7 \pm$ 3.1 ind. $\mathrm{d}^{-1}$ (Table 6). Thus, the metabolic demands of relatively inactive $S$. syrtensis, which often float passively according to observations made during the present and previous studies (Vecchione \& Young 1997, Collins et al. 2002), would be met by the prey available in $<1 \mathrm{~m}^{3}$ of water, given the mean abundance of $C$. finmarchicus measured across all 3 canyons in 2002.

The in situ observations made during the present study confirmed and expanded on knowledge of the distribution of Stauroteuthis syrtensis. This species has often been captured in bottom trawls (Collins \& Henriques 2000), and the octopods observed and captured during our study were, on average, approximately

Table 6. Stauroteuthis syrtensis. Metabolic demand, calculated from $\mathrm{O}_{2}$ consumption using an assumed respiratory quotient of 0.8 , and inferred maintenance ration based on the assumption that a single Calanus finmarchicus contained $0.234 \mathrm{mg}$ of $\mathrm{C}$

\begin{tabular}{|lcc|}
\hline Octopod & $\begin{array}{c}\text { Metabolic demand } \\
\left(\% \text { body } \mathrm{C} \mathrm{d}^{-1}\right)\end{array}$ & $\begin{array}{c}\text { Maintenance ration } \\
(\text { no. of copepods d }\end{array}$ \\
\hline 1 & 0.11 & 3.2 \\
2 & 0.43 & 2.9 \\
3 & 0.21 & 10.4 \\
4 & 0.59 & 2.3 \\
5 & 0.45 & 3.5 \\
6 & 0.27 & 1.3 \\
7 & 0.38 & 5.2 \\
8 & 0.12 & 1.5 \\
9 & 0.33 & 30.1 \\
Mean & 0.32 & 6.7 \\
\pm SE & \pm 0.05 & \pm 3.1 \\
\hline
\end{tabular}


$100 \mathrm{~m}$ off the bottom during the day and at night. The ecological importance of the statistically significant difference in mean depth between daytime and nighttime sightings remains uncertain. This difference represented approximately $4 \%$ of the total average depth of the water column. Observations of up to 5 octopods in a $400 \mathrm{~m}^{3}$ field of view indicated that trawl surveys yielding octopod abundance estimates of 8 to 9 ind. $\mathrm{km}^{-2}$ swept area may have integrated small-scale patches of octopods (Collins et al. 2001).

Although octopods may have sensed the submersible before they were sighted, in situ observations revealed that many individuals drifted in a 'sleeping mode,' with their bodies contracted into a relatively compact ball and their eyes hooded. In this posture, the octopod was difficult to distinguish from floating debris. This quiescent behavior was not exhibited by captive octopods. In response to disturbance caused by the submersibles, Stauroteuthis syrtensis inflated its web complex and exhibited the ballooning behavior noted previously (Vecchione \& Young 1997, Johnsen et al. 1999, Collins et al. 2002). Thus, observations in the present study supported the hypothesis that these behaviors may function as an alarm response to deter or confuse predators, such as Cuvier's beaked whales Ziphius cavirostris and blue sharks Prionace glauca (Vecchione \& Young 1997, Johnsen et al. 1999, Santos et al. 2001, Collins et al. 2002, Kubodera et al. 2007). Observations also indicated that slow sculling of the paired fins, medusoid contractions of the web, and rapid fin sculling were similar to patterns of locomotion reported for another deep-water cephalopod, Vampyroteuthis infernalis (Seibel et al. 1998). S. syrtensis seemed to employ this sequence of behaviors in response to increased levels of disturbance. The behaviors of $S$. syrtensis also resemble those described for other cirrate octopods (Boletzky et al. 1992, Hovland 1992, Villanueva et al. 1997).

In summary, the results of the present study confirmed that Stauroteuthis syrtensis is a deep-water species that often lives near the bottom. The octopods typically floated passively, and they responded to increasing disturbance by inflating their webs and employing progressively faster modes of locomotion to escape. S. syrtensis fed on the copepod Calanus finmarchicus, with relatively few prey needed to meet their basal metabolic demands. In general, the chemical content of S. syrtensis was more similar to gelatinous zooplankton than to more muscular cephalopods, but its $\mathrm{O}_{2}$ consumption was greater than that of gelatinous zooplankton and similar to other deepwater cephalopods that have been reported to be ambush predators. In addition, S. syrtensis excreted relatively little $\mathrm{NH}_{4}{ }^{+}$or $\mathrm{PO}_{4}{ }^{3-}$, and the octopods seemed to catabolize lipids, which could have been derived from C. finmarchicus.
Acknowledgements. We greatly appreciate the assistance provided by the crews of the RV 'Seward Johnson I' and 'Seward Johnson II', the crews of the 'Johnson-Sea-Link' submersibles and all participants in the research cruises. The study was supported by a grant to M.J.Y. from the National Science Foundation (NSF-0002493), the European Project Eurogel, and the United States Department of Agriculture Current Research Information System Project FLA-FAS-04611. This work represents HBOI/FAU Contribution Number 1723.

\section{LITERATURE CITED}

American Public Health Association (1989) Standard methods for the examination of water and wastewater: including bottom sediments and sludges, 17th edn. American Public Health Association, Washington, DC

Bailey TG, Torres JJ, Youngbluth MJ, Owen GP (1994) Effect of decompression on mesopelagic gelatinous zooplankton: a comparison of in situ and shipboard measurements of metabolism. Mar Ecol Prog Ser 113:13-27

Bailey TG, Youngbluth MJ, Owen GP (1995) Chemical composition and metabolic rates of gelatinous zooplankton from midwater and benthic boundary layer environments off Cape Hatteras, North Carolina, USA. Mar Ecol Prog Ser 122:121-134

Boletzky SV, Rio M, Roux M (1992) Octopod 'ballooning' response. Nature 356:199

Childress JJ, Mickel TJ (1985) Metabolic rates of animals from the hydrothermal vents and other deep-sea habitats. Bull Biol Soc Wash 6:249-260

Collins MA (2002) Cirrate octopods from Greenland and Iceland waters. J Mar Biol Assoc UK 82:1035-1036

Collins MA, Henriques C (2000) A revision of the family Stauroteuthidae (Octopoda: Cirrata) with redescriptions of Stauroteuthis syrtensis and S. gilchristi. J Mar Biol Assoc UK 80:685-697

Collins MA, Villanueva R (2006) Taxonomy, ecology and behaviour of the cirrate octopods. Oceanogr Mar Biol Annu Rev 44:277-322

Collins MA, Yau C, Allcock L, Thurston MH (2001) Distribution of deep-water benthic and bentho-pelagic cephalopods from the north-east Atlantic. J Mar Biol Assoc UK 81:105-117

Collins M, Young RE, Vecchione M (2002) Stauroteuthis syrtensis Verrill, 1879. Available at: http://tolweb.org/ Stauroteuthis_syrtensis/20187/2002.01.30. (Accessed on 17 January 2009)

Croxall JP, Prince PA (1982) Calorific content of squid (Mollusca: Cephalopoda). Br Antarct Surv Bull 55:27-31

Daly HI, Peck LS (2000) Energy balance and cold adaptation in the octopus Pareledone charcoti. J Exp Mar Biol Ecol 245:197-214

Hovland M (1992) Balloon response explanation? Nature 357: 119

Ikeda T, Mitchell AW (1982) Oxygen uptake, ammonia excretion and phosphate excretion by krill and other Antarctic zooplankton in relation to their body size and chemical composition. Mar Biol 71:283-298

Johnsen S, Balser EJ, Fisher EC, Widder EA (1999) Bioluminescence in the deep-sea cirrate octopod Stauroteuthis syrtensis Verrill (Mollusca: Cephalopoda). Biol Bull 197: 26-39

Katsanevakis S, Stephanopoulou S, Miliou H, MoraitouApostolopoulou M, Verriopoulos G (2005) Oxygen consumption and ammonia excretion of Octopus vulgaris (Cephalopoda) in relation to body mass and temperature. Mar Biol 146:725-732 
Krzynowek J, Murphy J (1987) Proximate composition, energy, fatty acid, sodium, and cholesterol content of finfish, shellfish, and their products. NOAA Tech Rep 55

Kubodera T, Watanabe H, Ichii T (2007) Feeding habits of the blue shark, Prionace glauca, and lemon shark, Lamna ditropis, in the transition region of the western North Pacific. Rev Fish Biol Fish 17:111-124

Mayzaud P, Conover RJ (1988) O:N atomic ratio as a tool to describe zooplankton metabolism. Mar Ecol Prog Ser 45: 289-302

Miller CB, Morgan CA, Prahl FG, Sparrow MA (1998) Storage lipids of the copepod Calanus finmarchicus from Georges Bank and the Gulf of Maine. Limnol Oceanogr 43:488-497

Moltschaniwskyj NA, Semmens JM (2000) Limited use of stored energy reserves for reproduction by the tropical loliginid squid Photololigo sp. J Zool (Lond) 251:307-313

Robison BH, Reisenbichler KR, Hunt JC, Haddock SHD (2003) Light production by the arm tips of the deep-sea cephalopod Vampyroteuthis infernalis. Biol Bull 205:102-109

Rosa R, Pereira J, Nunes M (2005) Biochemical composition of cephalopods with different life history strategies, with special reference to a giant squid, Architeuthis sp. Mar Biol 146:739-751

Santos MB, Pierce GJ, Herman J, Lopez A, Guerra A, Mente E, Clarke MR (2001) Feeding ecology of Cuvier's beaked whale (Ziphius cavirostris): a review with new information on the diet of this species. J Mar Biol Assoc UK 81: 687-694

Segawa S, Nomoto A (2002) Laboratory growth, feeding, oxygen consumption and ammonia excretion of Octopus ocellatus. Bull Mar Sci 71:801-813

Seibel BA, Carlini DB (2001) Metabolism of pelagic cephalopods as a function of habitat depth: a reanalysis using phylogenetically independent contrasts. Biol Bull 201:1-5

Seibel BA, Childress JJ (2000) Metabolism of benthic octopods (Cephalopoda) as a function of habitat depth and oxygen concentration. Deep-Sea Res I 47:1247-1260

Seibel BA, Theusen EV, Childress JJ, Gorodezky LA (1997) Decline in pelagic cephalopod metabolism with habitat depth reflects differences in locomotory efficiency. Biol Bull 192:262-278

Editorial responsibility: Hans Heinrich Janssen, Oldendorf/Luhe, Germany
Seibel BA, Theusen EV, Childress JJ (1998) Flight of the vampire: ontogenetic gait-transition in Vampyroteuthis infernalis (Cephalopoda: Vampyromorpha). J Exp Biol 201: 2413-2424

Seibel BA, Theusen EV, Childress JJ (2000) Light-limitation on predator-prey interactions: consequences for metabolism and locomotion of deep-sea cephalopods. Biol Bull 198:284-289

Seibel BA, Goffredi SK, Theusen EV, Childress JJ, Robison BH (2004) Ammonium content and buoyancy in midwater cephalopods. J Exp Mar Biol Ecol 313:375-387

Strickland JO, Parsons TR (1972) A practical handbook of seawater analysis. Bull Fish Res Board Can 167

Tietze RC, Clark AM (1986) Remotely operated tools for undersea vehicles. In: McGuiness T (ed) Current practices and new technology in ocean engineering. American Society of Mechanical Engineers, New York, p 219-223

Vecchione M, Galbraith J (2001) Cephalopod species collected by deepwater exploratory fishing off New England. Fish Res 51:385-391

Vecchione M, Pohle G (2002) Midwater cephalopods in the western North Atlantic Ocean off Nova Scotia. Bull Mar Sci 71:883-892

Vecchione M, Young RE (1997) Aspects of the functional morphology of cirrate octopods: locomotion and feeding. Vie Milieu 47:101-110

Villanueva R, Segonzac M, Guerra A (1997) Locomotion modes of deep-sea cirrate octopods (Cephalopoda) based on observations from video recordings on the Mid-Atlantic Ridge. Mar Biol 129:113-122

Wetzel RG, Likens GE (2000) Limnological analyses, 3rd edn. Springer, New York

Youngbluth MJ (1984) Manned submersibles and sophisticated instrumentation: tools for oceanographic research. In: Proceedings of Subtech 83 Symposium. Society for Underwater Technology, London, p 335-344

Youngbluth MJ, Kremer P, Bailey TG, Jacoby CA (1988) Chemical composition, metabolic rates and feeding behavior of the midwater ctenophore Bathocyroe fosteri. Mar Biol 98:87-94

Submitted: September 29, 2008; Accepted: November 28, 2008 Proofs received from author(s): January 21, 2009 